\title{
Reports from State and Local Child Labor Committees and Consumers' Leagues
}

\author{
Made to the National Committee at the Third Annual Convention, Held \\ in Cincinnati, December 13-15, 1906.
}

\section{REPORT OF THE NEW YORK CHILD LABOR COMMITTEE}

Since the last annual meeting of the National Child Labor Committee, in December, 1905, the New York committee has been actively engaged in pursuing the work for which it was organized in 1902, namely: "To increase the efficiency of existing child labor laws by securing legislation in the form of amendments which may seem necessary; to assist the authorities in the enforcement of laws relating to compulsory education and child labor, and to educate public sentiment concerning the preventing of child labor."

The legislative work of the committee at the last session of the New York legislature was attended with considerable success, and a number of measures were passed which mark a real advance in child labor legislation. The most notable of these was the law bringing New York State practically into line with Illinois, Ohio and Massachusetts in the matter of evening work. Formerly children under sixteen were allowed to work in factories in our state as late as $\mathbf{9}$ o'clock at night, and in stores, messenger offices, restaurants, hotels and apartment houses until Io o'clock. Since October I, 1906, the closing hour has become $7 \mathrm{p}$. m. for all establishments, with the exception of places outside of New York and Buffalo, where the ro o'clock provision regarding mercantile establishments remains unchanged. The enforcement of this new law will be watched with much interest, particularly in New York City, during the busy holiday season.

Through the vigorous protests of the committee and of its contributors and endorsers, a serious situation was averted last spring when the legislature early in the session not only failed to give the state department of labor a larger appropriation in order to increase the efficiency of this law-enforcing body, but reduced the appropriation $\$ 8,000$ under that of the previous year. As a result of the agitation of the committee and of other interested organizations and friends the department finally received the increased appropriation sought after, and the appointment of twelve additional inspectors was made possible. Several other bills which would have had a tendency to weaken the child labor law were actively opposed by the committee and failed of passage.

It is with much pleasure that the committee is able to report a marked improvement in the adequacy of the enforcement of the laws with respect 
to the employment of children in factories. The administration of Hon. P. Tecumseh Sherman, the head of the State Department of Labor, has been full of encouragement to the members of our committee. While not agreeing fully with all of the provisions of the law, he has shown a determination to conscientiously enforce the law in so far as he was able with the number of inspectors at the command of the department. The most notable advance made by this department has been in the matter of prosecutions of employers. For the year ending September 30, 1906, proceedings for violations of the law with respect to the employment of children were commenced against 121 employers, covering 192 instances of children illegally employed, and $\$ 810$ in fines were collected. The report for the year ending September 30, 1904, of the preceding commissioner of labor, shows fifteen employers prosecuted for illegally employing twenty-one children, and \$135 fines collected.

A great deal of attention of the committee has been centered upon efforts to secure through official channels a better enforcement of the compulsory education law. A careful study of the situation has shown that the ambiguity and complex wording of the present law are the most serious obstacles in the way of its proper enforcement. This is especially true in New York City with respect to attendance of children fourteen and fifteen years of age who are required to attend school unless regularly and lawfully at work. Our investigations have shown that the law breaks down seriously at this point, and it is therefore the desire of the committee to secure at the next session of the legislature some amendments which will meet this serious difficulty. Because of its great importance for compulsory attendance purposes, our committee for more than a year, together with other organizations, has been strongly urging an adequate school census of New York City. The taking of such a census every two years is required by a state law, but has been allowed to lapse since I897. As a result of the agitation of the committee and other social organizations the State Department of Education instituted the taking of such a census throughout the state in October of this year. The committee has been closely associated with the school officials in New York City who have been responsible for the enumeration, and has assisted, by suggestion and in other ways, in the preparation of the census schedule. Although begun on October $23 \mathrm{~d}$, the canvass throughout the five boroughs of Greater New York is not yet completed. The tabulation of the data secured is under way, but it will take several months to fully compile the facts. It remains to be seen whether or not the children shown by the census unlawfully absent from school are promptly followed up and placed in school. Unless immediate attention is given to this part of the work, the census will be of very little practical value for compulsory attendance purposes, because of the large amount of shifting of families from one address to another in a city of the population of New York.

In our state the enforcement of the laws with respect to the employment of children in stores, messenger offices, restaurants, hotels, apartment houses, etc., is in the hands of local health boards. A study of enforcement of these provisions under these boards has shown that there is a distinct tendency 
to subordinate this work to the sanitary duties of such health boards, much to the detriment of the enforcement of the child labor laws. If an adequate enforcement of the law by the present authorities cannot be secured, our committee will probably take steps to secure legislation transferring the responsibility to other authorities.

The condition of the street trades with respect to employment of children is as unsatisfactory as reported to this committee a year ago. The special squad of plain-clothes men assigned by the police department to the duty of enforcing the so-called newsboy law was transferred, in February last, to other duties, and the responsibility of enforcing the law was again put upon the regular uniformed police, with the result that the law is as much a dead letter as it was before the days of the special squad. As the members of our committee were not clear whether the fault for this condition was to be found in the law itself or in its administration, a paid investigator has been carefully studying the entire problem since July. It is hoped by the first of January to have a report upon this subject, and to be able then to reach some solution of the difficulty.

At the meeting of this committee a year ago Miss Lillian Wald, a member of the New York committee, spoke of the establishment of child labor scholarships by our committee. It will be recalled that these scholarships were created for the purpose of preventing hardship to a child laborer's family when the child's illegal earnings were really needed. An equally important object of these scholarships is to remove from the minds of officials who were charged with enforcing the law any fear of causing suffering to a family by requiring a full compliance with the law. This plan of substituting children's earnings where it was proved such earnings were genuinely needed, has now been in effect in New York City for nearly fifteen months. As the scheme has become better understood by school officials and others who refer applications for scholarships to our committee, there is a distinct tendency to bring to our attention more cases which are directly within the scope of the fund, and probably more instances of genuine poverty. Without going into details, it may be of interest to those present to know the general results of this work. For the year ending October 1, 1905-the first year of the plan-345 applications were received and investigated, either by the committee or at our request by representatives of the relief societies. Of this number 203, or 59 per cent, were deemed not to be in need of assistance. Of the remaining $\mathrm{I}_{42}$ cases, or $4 \mathrm{I}$ per cent, help in the form of scholarships was given in sixty-two instances, while in the other eighty cases, in many of which the need was only temporary, assistance was provided through the various relief societies. These scholarships vary in amount from $\$ 1$ to $\$ 3$ a week, and extend over a period of from three to thirteen months. The holders are required to present weekly at the office of the committee a card signed by the school principal certifying to their regular attendance at school. For the first year $\$ 2,500$ was placed at the disposal of the committee for this work, and this ampunt was sufficient to meet all demands upon the funds. The large number of applications for 
assistance from this fund which have been coming to the committee during the first quarter of the second year of this work indicates that from $\$ 1,000$ to $\$ 2,000$ additional will probably be necessary to meet the needs of this work for the second year. We are happy to announce that this additional money has been already promised, so that the continuance of the plan is assured. The committee is convinced of the practical value of this plan, not so much as a means of assisting worthy families, but for the purpose of disarming public criticism in regard to the poverty plea for child labor. Another very valuable result of this phase of our work is the moral and educational effect upon both children and officials that the law cannot be evaded. Much important data, otherwise unobtainable, regarding the way in which the laws are actually being enforced, has also been secured through the correspondence and visiting of our paid visitor for scholarship work.

A new line of investigation has recently been entered upon by our committee, namely, a study of the condition of children working in tenement homes. In conjunction with the College Settlement Association of New York City and the Consumers' League, a paid investigator is now giving all her time to this work, and is finding startling conditions among the child workers in the dark and badly ventilated tenements of our great city. It is hoped that in the near future some legislation may be secured to protect these children, who, if attending school, are not at present otherwise covered by the law.

For the coming year the committee has under consideration the following subjects for a legislative action; a prohibition against the employment of children under sixteen in the fourteen dangerous occupations specified in the Illinois law:

An eight-hour day for children; a transfer to the children's courts of jurisdiction over cases against employers for violating provisions of the labor law, and against parents for allowing children to remain unlawfully absent from school, and appointment of additional inspectors to strengthen the hands of the department of labor.

New York, December 12, 1906.

Grorge Hatd, Secretary.

\section{REPORT OF THE MISSOURI CHILD LABOR COMMITTEE.}

I. The comfortable conviction that Missouri has been and is relatively free from the evils of child labor has, I think, been rather widely cherished by good people in this state. The laws, though confessedly not models of their kind, at least prohibit the employment of children under fourteen in factories and mines; the industries which most tempt to violations of such laws-the textile and glass industries and coal mining - are among the least important in the state; and these two facts have sufficed to engender the optimistic supposition that, although there was doubtless room for improvement, Missouri was on the whole fairly well off in this respect. To this 